\title{
First discovery and characterizations of late Cretaceous seep carbonates from Xigaze in Tibet, China
}

\author{
TONG HongPeng ${ }^{1,2} \&$ CHEN DuoFu ${ }^{1 *}$ \\ ${ }^{1}$ CAS Key Laboratory of Marginal Sea Geology, Guangzhou Institute of Geochemistry, Chinese Academy of Sciences, Guangzhou 510640, China; \\ ${ }^{2}$ Graduate University of Chinese Academy of Sciences, Beijing 100049, China
}

Received May 31, 2012; accepted July 30, 2012; published online September 6, 2012

\begin{abstract}
Hydrocarbon seeps, widely occurring in continental margins, have become increasingly focused owing to their close relationships with gas hydrates, strong greenhouse gas methane, and biological resources in extreme environments. Ancient hydrocarbon seeps have already been recognized from Devonian to Quaternary strata worldwide based on seep carbonates or seep-related fossil chemosynthetic assemblages. However, seep-related deposits are rarely found from ancient strata in the mainland China. Here, we report the first discovery of an ancient seep deposit, specifically late Cretaceous seep carbonates from Xigaze in Tibet, China. Xigaze seep carbonates, occurring as nodules, are enclosed in upper Cretaceous turbidite strata in Xigaze forearc basin. These carbonates are composed of authigenic carbonate (56.2\% on average), clastic quartz and feldspar (27.3\% on average), and clay minerals (chlorite, illite and smectite, $16.5 \%$ on average). Clotted micrites, peloids and framboid pyrites are frequently observed, all of which are common in modern seep carbonates. The carbonates have negative $\delta^{13} \mathrm{C}$ values varying from $-27.7 \%$ to $-4.0 \%$ o (V-PDB), suggesting that thermogenic methane is the primary carbon source. $\mathrm{Ce} / \mathrm{Ce} *$ values revised by eliminating La effects show no real $\mathrm{Ce}$ anomaly, indicating the carbonates were primarily precipitated in a weak reducing environment. Overall, these features provide unequivocal evidences that the seafloor of Xigaze forearc basin developed hydrocarbon seeps in late Cretaceous.
\end{abstract}

seep carbonate, carbon isotope, sedimentary fabric, Xigaze, late Cretaceous

Citation: Tong H P, Chen D F. First discovery and characterizations of late Cretaceous seep carbonates from Xigaze in Tibet, China. Chin Sci Bull, 2012, 57: 4363-4372, doi: 10.1007/s11434-012-5434-2

Cold seeps are frequently observed in marine settings of continental margins worldwide, and the last 30 years' investigations show that they are known from the tropics to the poles, in shallow shelf to hadal depths [1-11]. The seep fluids are commonly composed of water and methane, and occasionally heavy hydrocarbons, such as crude oil. Seeping methane could partially occur as gas hydrates below the seafloor at suitable temperature and pressure [7-9]. Chemosynthetic assemblages are often observed in cold seep environment $[3,4,8]$. Cold seeps, therefore, are becoming increasingly focused in the field of ocean sciences.

When migrating towards the seafloor, seeping methane would set off anaerobic oxidation (AOM: $\mathrm{CH}_{4}+\mathrm{SO}_{4}^{2-} \rightarrow$ $\left.\mathrm{HCO}_{3}^{-}+\mathrm{HS}^{-}+\mathrm{H}_{2} \mathrm{O}\right)$ mediated by the methane-oxidizing ar-

*Corresponding author (email: cdf@gig.ac.cn) chaea and the sulfate-reducing bacteria at the sulfate-methane transition zone (SMT) [12-15]. This reaction increases the water saturation state with respect to the bicarbonate $\left(\mathrm{HCO}_{3}^{-}\right)$, which favors precipitation of carbonate minerals, forming so-called seep carbonates $[1,2,14]$. Therefore, seep carbonates are fingerprint files of past cold seepage activities.

The diagnostic features of ancient seep carbonates commonly include low $\delta^{13} \mathrm{C}$ values of early diagenetic carbonate phases, special sedimentary fabrics such as clotted micrites, peloids and framboid pyrites, the occurrence of low diversity but high abundance faunal assemblage fossils and distinct ${ }^{13} \mathrm{C}$-depleted biomarkers [10,13,14,16-21]. Since the "seep-search strategy" was proposed by Campbell and Bottjer [22], more and more ancient seep deposits were discovered and studied. Today, ancient hydrocarbon seeps have already been recognized from Devonian to Quaternary 
strata in almost all continents based on occurrences of seep carbonates and/or fossil chemosynthetic assemblages [10,13,14,16-20,23-28]. However, seep carbonates are rarely found from ancient strata in the mainland China. A controversial one is the cap carbonate at the bottom of Doushantuo Formation in the Three Gorges area. This carbonate exhibits $\delta^{13} \mathrm{C}$ value lower than $-40 \%$, but the origin of the carbonate is still controversial [29-32]. In addition, Zhou et al. [33] proposed that the rhodochrosites in the Datangpo Formation of the Nanhua Series in northeastern Guizhou were seep carbonates, but the formation of these deposits has always been a controversial topic.

Here, we report the first definite ancient seep deposit discovered in the mainland China, late Cretaceous seep carbonates in Xigaze, Tibet. The seep carbonates, occurring as nodules, are enclosed in upper Cretaceous turbidite strata in Xigaze forearc basin. These carbonate nodules have extremely low $\delta^{13} \mathrm{C}$ values and special sedimentary fabrics such as clotted micrites, peloids and framboid pyrites, confirmedly indicating typical cold seepage origins. And, the possible seepage fluid characterizations and formation conditions for Xigaze seep carbonates were proposed on the basis of field occurrences, mineralogical and geochemical characteristics.

\section{Samples and methods}

The Xigaze seep carbonates discussed here are exposed beside the 318 National Highway in the northern Kardio village, Xigaze, Tibet (Figure 1(a)). They are enclosed in the mudstone turbidite of Angren Formation deposited in late Cretaceous Xigaze forearc basin [34]. Seep carbonates here occur as 4 mutually parallel nodule layers stretching several meters long (Figure 1(b)). These nodules can be easily distinguished from the enclosing rocks. They exhibit spherical or irregular ellipsoid shapes about $3 \mathrm{~cm}$ to over 20 $\mathrm{cm}$ in diameter (Figure 1(c)). It can still be identified that the laminae of enclosing rocks are around the nodules, indicating syndepositional characterizations (Figure 1(c)). The 4 parallel nodule layers are all sampled and named as the first (KDN1), the second (KDN2), the third (KDN3) and the fourth layers (KDN4) from the bottom to the top, respectively.

Carbonate nodules from the four layers were crushed into small pieces, and fresh ones were chosen under binocular microscope. The sorted samples were ground to less than 200 mesh for the use of X-Ray Diffraction (XRD), major element, stable carbon and oxygen isotope and rare earth element (REE) analyses. Additional powder was drilled using a hand-held microdrill from polished nodule surfaces for carbon and oxygen isotope analyses.

Petrographic observations of thin sections were made using a LEICA-DMRX optical microscope and photographs were taken with a LEICA DC500. The microfabrics of seep
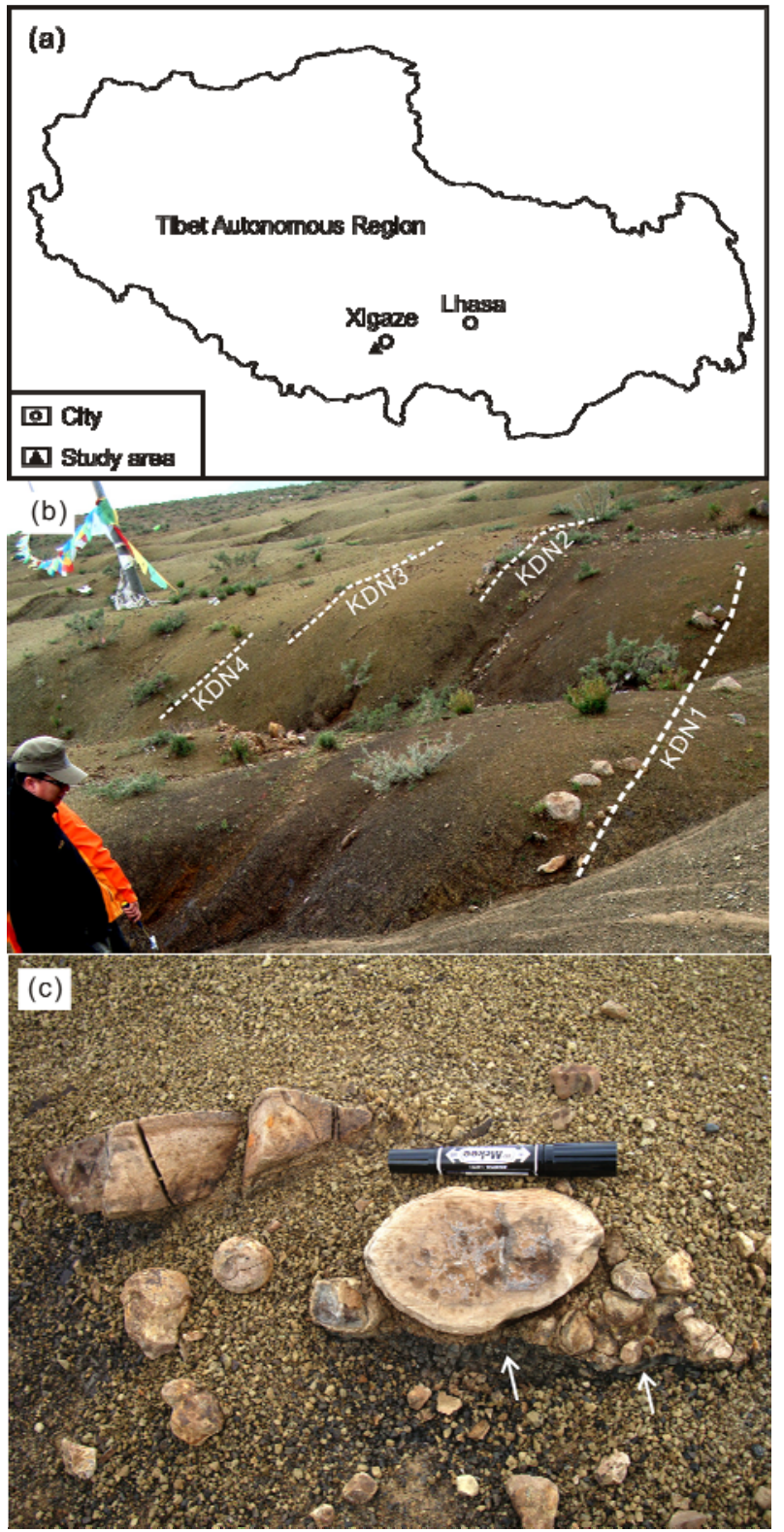

Figure 1 Sampling location, field profile, and nodule occurrences of the late Cretaceous seep carbonates in Xigaze, Tibet. (a) General location map; (b) field occurrences showing that four parallel carbonate nodule layers are enclosed in the strongly weathered turbidite; (c) the third nodule layer exhibits that laminae of enclosing rocks (arrows) around nodules indicating syndepositional characterizations.

carbonates were examined on fresh surfaces using a Quanta 400 Scanning Electron Microscope (SEM), housed in Guangzhou Institute of Geochemistry, Chinese Academy of Sciences (GIG, CAS). Bulk mineralogy was determined by XRD using a Bruker AXS D8 Advance X-Ray diffractometer (GIG, CAS). The X-ray source was a $\mathrm{Cu}$ anode operated at $40 \mathrm{kV}$ and $40 \mathrm{~mA}$ using $\mathrm{Cu} \mathrm{K} \alpha$ radiation equipped with a diffracted beam graphite monochromator. Orientated samples were scanned at an interval of $5-65^{\circ}(2 \theta)$ with a step size of $0.02^{\circ}$ and count time of $5 \mathrm{~s}$ per step. Diverging, scattering, and receiving slits were $0.5^{\circ}, 0.5^{\circ}$, and $0.15 \mathrm{~mm}$, 
respectively. The quantification of relative proportions of different carbonate minerals were performed on the basis of peak areas following the method by Roberts et al. [35]. Calcite with $\mathrm{MgCO}_{3}$ over $5 \mathrm{~mol} \%$ is considered as high Mg-calcite (HMC).

Carbon and oxygen isotope analyses were made with a GV Isoprime II stable isotopic mass spectrometry at GIG, CAS. The $\mathrm{CO}_{2}$ was liberated by reacting with $100 \%$ phosphoric acid at $90^{\circ} \mathrm{C}$. Measurement results were relative to the Vienna-Pee Dee Belemnite (V-PDB) standard. The precisions for $\delta^{13} \mathrm{C}$ and $\delta^{18} \mathrm{O}$ are better than $\pm 0.05 \%$ and $\pm 0.08 \%$, respectively. We analyzed rare earth element (REE) contents using a Finnigan MAT ELEMENT high resolution Inductively Coupled Plasma Mass Spectrometry (ICP-MS) at Institute of Geochemistry, CAS. The powder sample $(\sim 0.5 \mathrm{~g})$ was treated with $50 \mathrm{~mL}$ of $5 \% \mathrm{HNO}_{3}$ in a centrifuge tube for about $30 \mathrm{~min}$. Then, $2500 \mathrm{ng}$ of rhodium was added as an internal standard for calculating the element concentration of the dissolved carbonate mineral phase. Five milliliters of this solution were further diluted 10 times for analysis. The average standard deviations are less than $10 \%$, and average relative standard deviations are better than $5 \%$.

\section{Results}

\subsection{Sedimentology and mineralogy}

Xigaze carbonate nodules include two textural types, the massive and the laminated (Figure 2). The latter type only presents in the second nodule layer. Massive nodules commonly have a yellow surface because of weathering and a gray center (Figure 2(a)-(c)). The center parts consist of gray fine crystalline or microcrystalline carbonate matrix and scattered black peloids mainly composed of micrite carbonate minerals (Figure 3(a)-(d)). The laminated nodules with dark gray fresh sections show bright and dark laminae alternated on millimeter scales (Figure 2(d),(e)). The bright laminae are thinner and have relatively high clastic contents (Figure 3(d)), and the dark ones are mainly of brown clotted micrite (Figure 3(e)). Sparry spheres with dark rims are observed in nodules from the first and the second layers. These spheres range in diameter from 50 to $200 \mu \mathrm{m}$ and do not show any complex internal fabrics (Figure 3(d) and (f)). They are mainly made of single crystal or polycrystalline carbonate.

The massive and the laminated nodules all develop pyrites showing framboids or subhedral to euhedral crystals. Framboid pyrites occur in peloids and clotted micrite (Figure 3(b) and (f)), whereas subhedral to euhedral crystals occur in the matrix of massive nodules (Figures 2(c),3(a) and (c)). Individual framboids are generally less than $10 \mu \mathrm{m}$ in diameter. They are formed of smaller globules or cubes that can exhibit complex fabrics (Figure 4 (a),(b)). For instance, the sunflower-like fabric was observed, which is composed of elongated crystals as the outer part and granular crystals as the central part (Figure 4(c)). Subhedral to
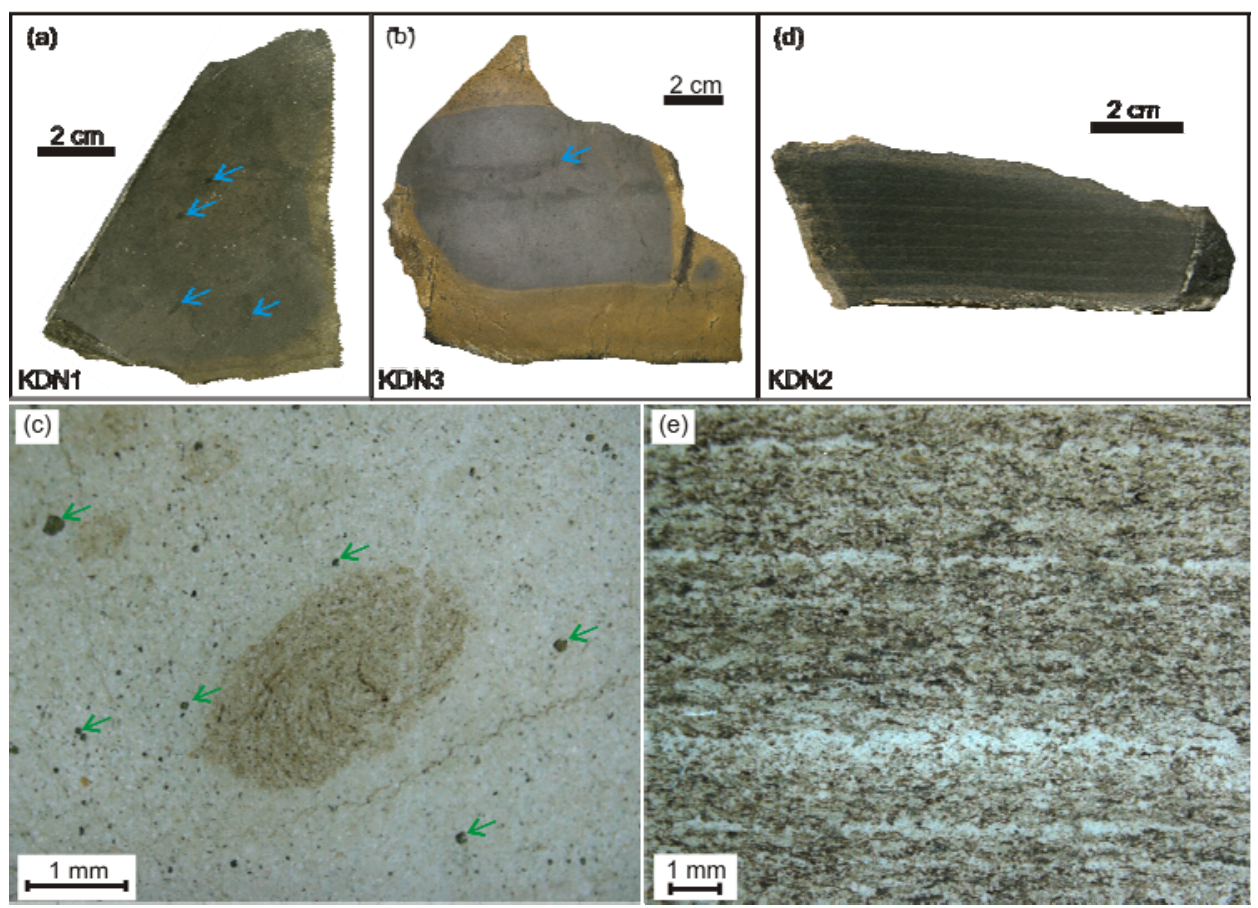

Figure 2 Typical morphologies of Xigaze carbonate nodules. (a) and (b) Massive nodules showing yellow surfaces and margins owing to weathering, and gray centers. Note the scattered black peloids (blue arrows); (c) a stereoscope photo of thin section of the gray matrix. Note the peloids and pyrite crystals with various sizes (green arrows); (d) laminated nodule consisting of bright and dark laminae alternated on millimeter scales; (e) a stereoscope photo of thin section of the laminated nodule. (a) and (c) images of the sample from the first nodule layer; (b) from the third layer, (d) and (e) from the second layer. 

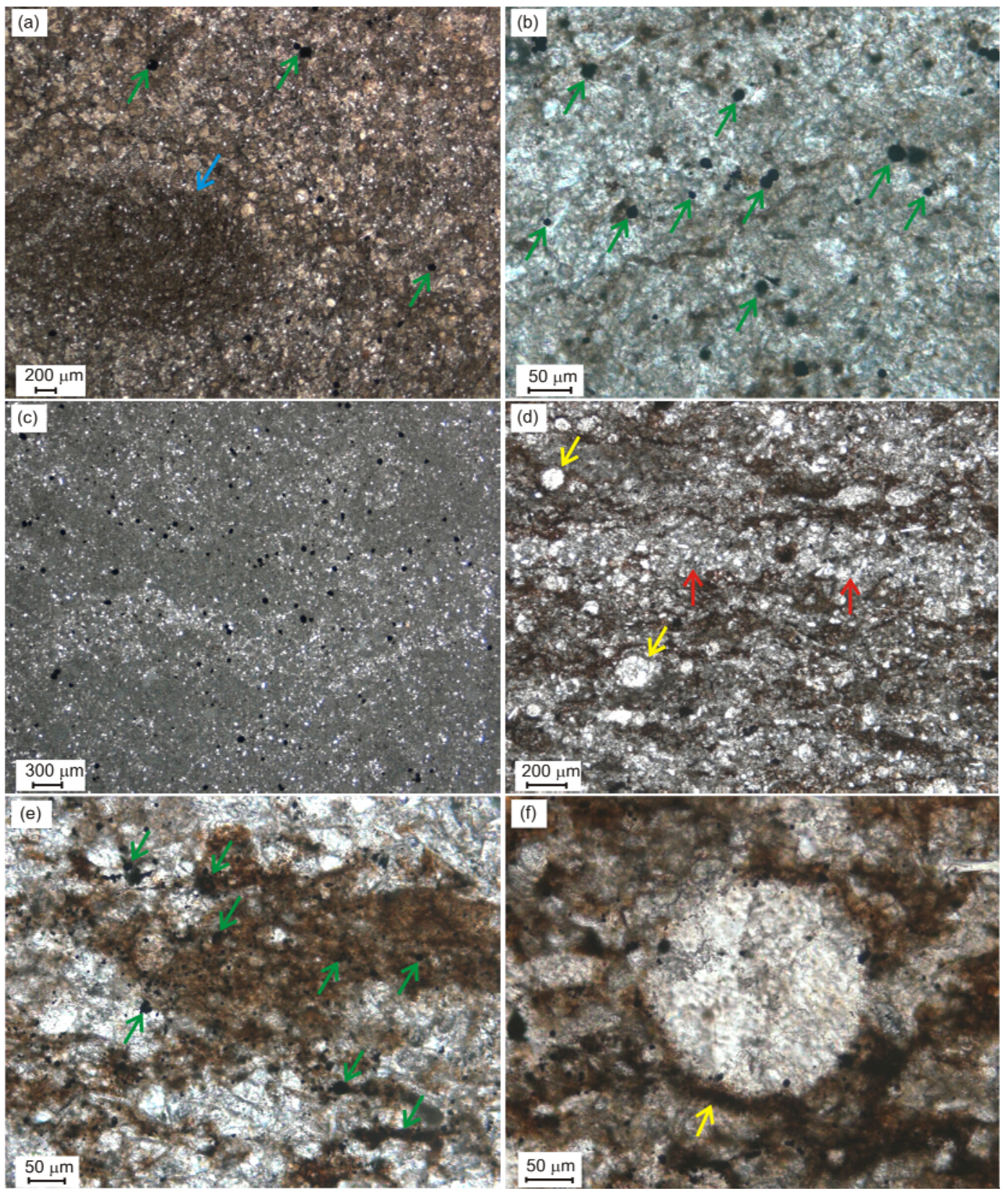

Figure 3 Microscopic images of Xigaze carbonate nodules. (a) A massive nodule from the first nodule layer consisting of fine crystalline carbonate matrix and micrite peloids (blue arrows). Subhedral pyrite crystals (green arrows) occur in matrix; (b) an enlarged image of micrite peloids. Note pyrite framboids in it (green arrows) which have diameters about $10 \mu \mathrm{m}$; (c) a massive nodule from the third nodule layer composed of microcrystalline carbonate matrix and fine grained calstic minerals. Black subhedral to euhedral pyrite crystals scatter in it; (d) laminated nodule from the second nodule layer showing alternated bright and dark laminae. The bright lamina (red arrows) develops more clastic contents, and the dark lamina is of brown clotted micrites. Note the sparry spheres with dark rims (yellow arrows); (e) clotted micrites and framboid pyrites (green arrows) in dark laminae of nodules from the second nodule layer; (f) enlarged view of a sphere with diameter about $200 \mu \mathrm{m}$ showing the dark rim (yellow arrow) and the sparry internal fabric in the sample from the second nodule layer. All photos were taken under polarized light microscope.

euhedral pyrite crystals from 10 to $100 \mu \mathrm{m}$ in diameter were observed. The crystals are well preserved, except those in samples from the fourth nodule layer showing obvious dissolution (Figure 4(d)).

Bulk mineralogy shows that the carbonate nodules are composed of authigenic carbonate (56.2\% on average), clastic quartz and feldspar (27.3\% on average), and clay minerals (16.5\% on average) (Table 1). The authigenic carbonate minerals of samples from the first and the second layers have both low Mg-calcite (LMC) and high Mg-calcite (HMC), while those from the third and the fourth layers show only LMC (Table 1).

\subsection{Stable carbon and oxygen isotopes}

The $\delta^{13} \mathrm{C}$ values of carbonate phases in Xigaze nodules vary 

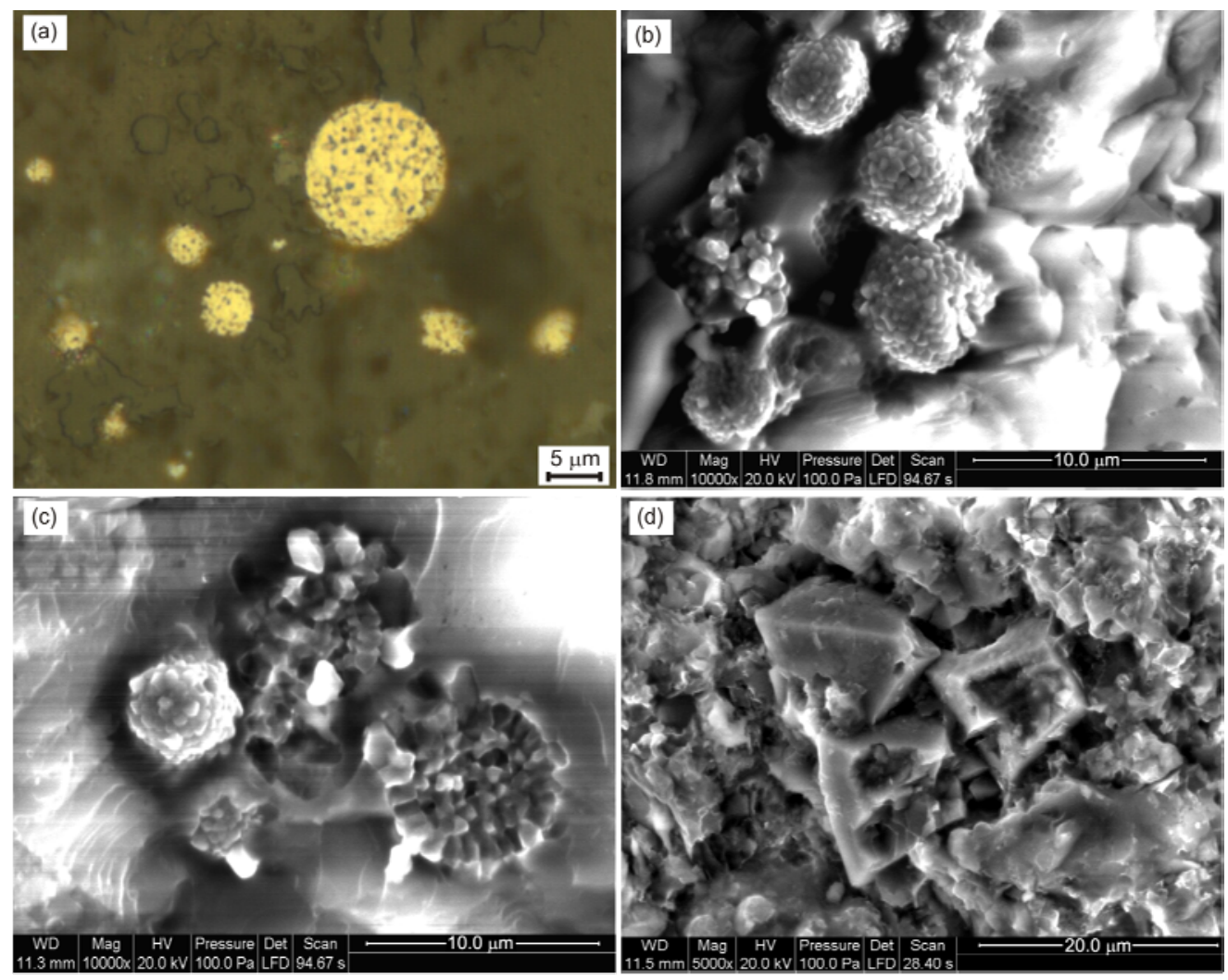

Figure 4 Microfabrics of pyrites in Xigaze carbonate nodules. (a) and (b) Framboid pyrites with diameters varying from 3 to $10 \mu \mathrm{m}$; (c) sunflower-like fabric within an individual framboid, which is composed of elongated crystals as the outer part and granular crystals as the central part; (d) dissolution of pyrite crystals in the nodule from the fourth layer. (a) An image under a reflected light microscope; (b)-(d) SEM images.

Table 1 Mineral composition of carbonate nodules from Xigaze (\%)

\begin{tabular}{lllccccc}
\hline Sample & LMC & HMC & Quartz & Feldspar & Chlorite & Illite & Smectite \\
\hline KDN1 & 41.9 & 17.3 & 10.3 & 4.7 & 5.7 & 7.4 & 12.7 \\
KDN2-1 & 37.1 & 43.0 & 8.0 & 2.6 & 4.4 & 4.9 & \\
KDN3-1 & 56.5 & & 22.3 & 5.0 & 6.4 & 9.8 & \\
KDN3-2 & 53.6 & & 28.8 & 4.6 & 4.7 & 6.3 & \\
KDN4-1 & 31.7 & & 43.5 & 6.6 & 6.6 & 11.6 & \\
\hline
\end{tabular}

a) LMC: low Mg-calcite; HMC: high Mg-calcite.

from $-27.7 \%$ to $-4.0 \%$ (V-PDB) (Table 2 and Figure 5). The laminated nodules from the second layer show the most negative $\delta^{13} \mathrm{C}$ values, from $-27.7 \%$ o to $-22.8 \%$. Those massive nodules from the first, the third and the fourth layers exhibit $\delta^{13} \mathrm{C}$ values of $-24.4 \%$ o to $-18.7 \%$, $-6.4 \%$ o to $-4.0 \%$, and $-11.6 \%$ o to $-8.0 \%$, respectively.

Xigaze carbonate nodules have relatively light oxygen isotope compositions with $\delta^{18} \mathrm{O}$ values ranging from $-10.7 \%$ o to $-4.3 \%$ (V-PDB) (Table 2 and Figure 5). Samples from the first to the fourth layers show $\delta^{18} \mathrm{O}$ values of $-8.0 \%$ to $-5.3 \%$ o, $-7.6 \%$ o to $-5.0 \%$ o, $-10.1 \%$ o to $-4.3 \%$ and $-10.7 \%$ o to $-7.1 \%$, respectively.

\subsection{Rare earth elements}

The results of REE analysis are listed in Table 3. The total
REE contents of carbonate phases in Xigaze carbonate nodules range from 84 to $195 \mathrm{ppm}$. Ce/Ce* values vary from 0.65 to 0.86 (Table 3), but the revised results (Figure 6) following Bau and Dulski's method [36] indicate no real Ce anomaly.

\section{Discussion}

\subsection{Sources of seep fluids}

The stable carbon isotope is commonly used to trace carbon sources of authigenic carbonates. Xigaze carbonate nodules exhibit $\delta^{13} \mathrm{C}$ values from $-27.7 \%$ to $-4.0 \%$ (V-PDB), which are much lower than that of the normal dissolved inorganic carbon in the coeval seawater (about 2\%o according to Veizer et al. [37]). However, the $\delta^{13} \mathrm{C}$ values of the carbonates 
Table 2 Stable carbon and oxygen isotopic compositions of carbonate phases of Xigaze carbonate nodules (V-PDB)

\begin{tabular}{|c|c|c|c|}
\hline Sample & Type & $\delta^{13} \mathrm{C}(\% \circ)$ & $\delta^{18} \mathrm{O}(\% \circ)$ \\
\hline KDN1-a & micrite peloid & -21.1 & -8.0 \\
\hline KDN1-b & micrite peloid & -18.7 & -5.7 \\
\hline KDN1-c & micrite peloid & -18.8 & -6.9 \\
\hline KDN1-d & micrite peloid & -18.7 & -6.5 \\
\hline KDN1-e & gray matrix & -24.4 & -6.3 \\
\hline KDN1-f & gray matrix & -23.9 & -6.9 \\
\hline KDN1-g & gray matrix & -23.5 & -5.3 \\
\hline KDN2-a & gray matrix & -24.7 & -7.5 \\
\hline KDN2-b & dark lamina & -22.8 & -5.0 \\
\hline KDN2-c & dark lamina & -26.3 & -7.6 \\
\hline KDN2-d & dark lamina & -26.4 & -7.1 \\
\hline KDN2-e & dark lamina & -26.3 & -7.1 \\
\hline KDN2-f & dark lamina & -25.0 & -5.6 \\
\hline KDN2-g & dark lamina & -25.5 & -5.1 \\
\hline KDN2-h & dark lamina & -27.7 & -6.5 \\
\hline KDN2-i & dark lamina & -27.6 & -6.6 \\
\hline KDN3-a & gray bulk & -5.3 & -6.9 \\
\hline KDN3-b & yellow bulk & -6.4 & -10.1 \\
\hline KDN3-c & gray matrix & -5.1 & -6.2 \\
\hline KDN3-d & gray matrix & -4.0 & -4.3 \\
\hline KDN4-a & yellow bulk & -9.5 & -10.7 \\
\hline KDN4-b & yellow matrix & -8.7 & -9.2 \\
\hline KDN4-c & yellow matrix & -10.2 & -9.5 \\
\hline KDN4-d & yellow matrix & -11.5 & -10.3 \\
\hline KDN4-e & yellow matrix & -11.6 & -10.5 \\
\hline KDN4-f & yellow matrix & -8.0 & -9.0 \\
\hline KDN4-g & yellow matrix & -9.9 & -9.3 \\
\hline KDN4-h & gray matrix & -10.0 & -7.1 \\
\hline
\end{tabular}

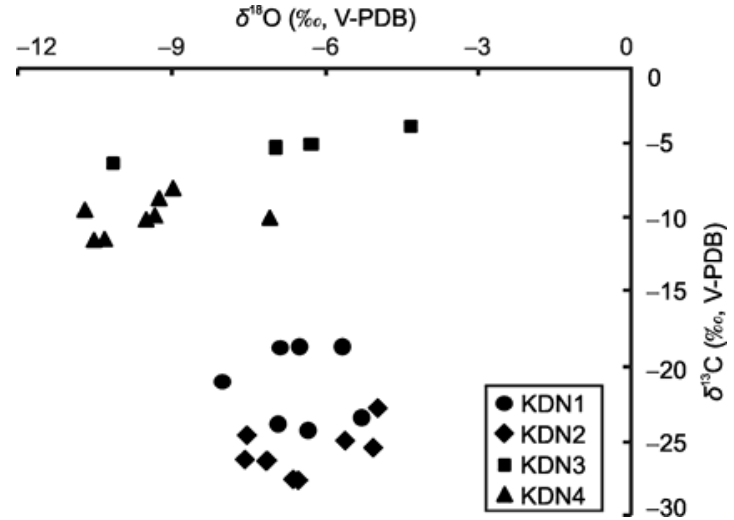

Figure 5 Stable carbon and oxygen isotope plot of Xigaze carbonate nodules.

show consistency with the ${ }^{13} \mathrm{C}$-depleted modern seep carbonates in carbon isotope compositionns $[1,2,11,35,38]$. In addition, laminae of enclosing rocks are around the nodules, indicating syndepositional characteristics. Therefore, it can be reasonably inferred that these Xigaze carbonate nodules are syndepositional products of oxidation of the seeping hydrocarbon.

Possible seeping hydrocarbon includes methane (with $\delta^{13} \mathrm{C}$ values of $-110 \%$ o to $-30 \%$ o $\left.[39,40]\right)$ and crude oil (with $\delta^{13} \mathrm{C}$ values of $-35 \%$ o to $-25 \%$ [1]). Modern and ancient seep carbonates derived from crude oil usually show degradated oil or bitumen remains, or develop bitumen inclusions [17,41]. But no similar materials were found in Xigaze seep carbonates, revealing that they are not derived

Table 3 REE concentrations of carbonate phases in Xigaze carbonate nodules (ppm)

\begin{tabular}{|c|c|c|c|c|c|c|c|}
\hline Sample & KDN1 & KDN2-1 & KDN2-2 & KDN3-1 & KDN3-2 & KDN4-1 & KDN4-2 \\
\hline $\mathrm{La}$ & 25.338 & 28.079 & 28.762 & 41.737 & 41.272 & 43.300 & 50.600 \\
\hline $\mathrm{Ce}$ & 32.013 & 31.341 & 33.329 & 57.432 & 57.365 & 69.800 & 80.700 \\
\hline $\operatorname{Pr}$ & 3.690 & 3.390 & 3.546 & 6.072 & 6.174 & 7.060 & 7.930 \\
\hline $\mathrm{Nd}$ & 13.300 & 12.145 & 12.415 & 22.087 & 22.936 & 27.500 & 30.600 \\
\hline $\mathrm{Sm}$ & 2.591 & 2.145 & 2.171 & 3.777 & 4.217 & 4.900 & 5.390 \\
\hline $\mathrm{Eu}$ & 0.703 & 0.494 & 0.471 & 0.969 & 1.121 & 1.047 & 1.170 \\
\hline Gd & 2.727 & 2.431 & 2.542 & 4.519 & 5.107 & 5.606 & 6.287 \\
\hline $\mathrm{Tb}$ & 0.387 & 0.305 & 0.339 & 0.581 & 0.715 & 0.809 & 0.900 \\
\hline Dy & 1.952 & 1.462 & 1.598 & 2.908 & 3.891 & 4.220 & 4.800 \\
\hline Но & 0.405 & 0.291 & 0.327 & 0.608 & 0.862 & 0.821 & 0.998 \\
\hline $\mathrm{Er}$ & 1.211 & 0.844 & 0.950 & 1.810 & 2.561 & 2.370 & 2.990 \\
\hline $\mathrm{Tm}$ & 0.170 & 0.112 & 0.127 & 0.249 & 0.344 & 0.305 & 0.377 \\
\hline $\mathrm{Yb}$ & 1.090 & 0.701 & 0.778 & 1.522 & 2.128 & 1.930 & 2.390 \\
\hline $\mathrm{Lu}$ & 0.190 & 0.118 & 0.128 & 0.254 & 0.355 & 0.296 & 0.344 \\
\hline$\sum \mathrm{REE}$ & 85.768 & 83.859 & 87.481 & 144.525 & 149.050 & 169.964 & 195.476 \\
\hline $\mathrm{Ce} / \mathrm{Ce}^{* \mathrm{a})}$ & 0.702 & 0.646 & 0.671 & 0.763 & 0.762 & 0.855 & 0.856 \\
\hline $\operatorname{Pr} / \mathrm{Pr}^{* b)}$ & 1.052 & 1.021 & 1.023 & 1.002 & 1.001 & 0.947 & 0.937 \\
\hline
\end{tabular}

a) Ce/Ce* denotes $3 \mathrm{Ce}_{N} /\left(2 \mathrm{La}_{\mathrm{N}}+\mathrm{Nd}_{\mathrm{N}}\right)$; b) Pr/Pr* denotes $\operatorname{Pr}_{\mathrm{N}} /\left(0.5 \mathrm{Ce}_{\mathrm{N}}+0.5 \mathrm{Nd}_{\mathrm{N}}\right)$, where $\mathrm{N}$ refers to normalization of concentration against the standard Post Archean Australian Shale. 


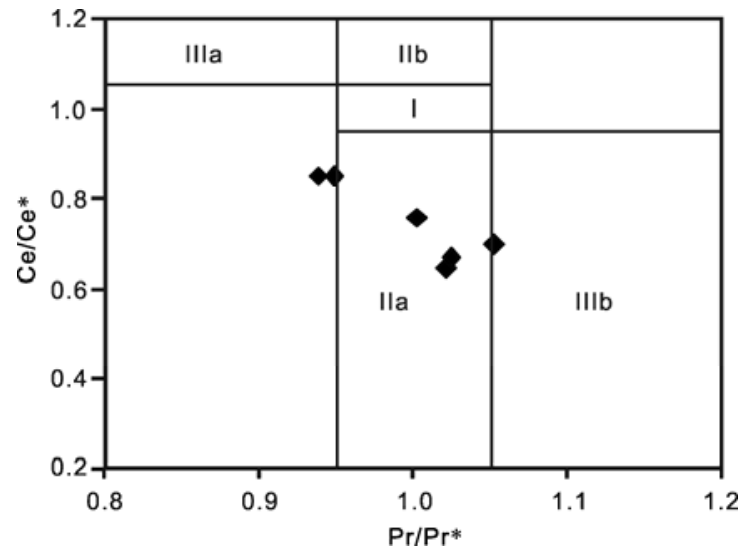

Figure 6 Plot of Ce/Ce* and $\mathrm{Pr} / \mathrm{Pr} *$. Field I: neither Ce nor La anomaly; field IIa: positive La anomaly, no Ce anomaly; field IIb: negative La anamaly, no Ce anomaly; field IIIa: real positive Ce anomaly; field IIIb: real negative Ce anomaly [36].

from crude oil and methane is the primary carbon source.

Seeping methane mainly contains two sources, the thermogenic (with $\delta^{13} \mathrm{C}$ values of $-50 \%$ to $-30 \%$ [39]) and the biogenic (with $\delta^{13} \mathrm{C}$ values of $110 \%$ to $-50 \%$ [ [40]). It need to be stressed that near the stratigraphic section of Xigaze seep carbonates, about 10-m-thick sedimentary tuff turbidite and a bentonite layer were reported in the lower strata [34]. Smectite occurs in carbonate nodules from the first layer. Thus, the coeval volcanic activities are suggested, which consequently caused the rapid maturity of hydrocarbons. Therefore, it is supposed that thermogenic methane is the primary carbon source for the studied Xigaze seep carbonates.

AOM preferentially consumes light isotope $\left({ }^{12} \mathrm{C}\right)$ from the carbon pool resulting in isotopically light $\mathrm{HCO}_{3}^{-}$compared to the carbon pool. Thus, theoretically, seep carbonates should have $\delta^{13} \mathrm{C}$ values much lower than or at least similar to the seepage hydrocarbon. However, modern cold seep examples illustrate that most seep carbonates have relatively heavy carbon isotopes compared to the seepage hydrocarbon, with the difference of $\delta^{13} \mathrm{C}$ values even more than $50 \%$ o $[14,42]$. This phenomenon suggests an inevitable ${ }^{13} \mathrm{C}$-enriched carbon source incorporated in cold seep carbonates, possibly the normal marine dissolved inorganic carbon or deep sourced dissolved inorganic carbon [43]. Mixing of these carbon sources in different proportion, due to changes of methane fluxes and flow rates, causes the large variations of $\delta^{13} \mathrm{C}$ values of seep carbonates. The diversity of sizes and occurrences of Xigaze seep carbonates reflect varied methane fluxes and flow rates of the cold seeps. Therefore, the relatively heavy carbon isotope of Xigaze seep carbonates compared to that of the seepage thermogenic methane and the large variation in $\delta^{13} \mathrm{C}(-27.7 \%$ o to $-4.0 \%$ ), may be accounted for the admixture of the strongly ${ }^{13} \mathrm{C}$-depleted carbon from AOM and the dissolved inorganic carbon from normal marine pore water and deepsourced seepage fluids.
In addition, the organoclastic sulfate reduction is modeled to contribute to the dissolved inorganic carbon in pore water at the methane-sulfate transition in the cold seep environment [43]. Thus, in situ oxidized organic matters could offer carbon to cold seep carbonates, as well. Since no fractionation was expected during the oxidation of organic molecules, authigenic carbonates directly derived from this process should have $\delta^{13} \mathrm{C}$ values similar to their parent carbon of the marine organic matters, with a mean of about $-25 \%$. Isotopically, these kinds of carbonates could hardly be distinguished from others with similar carbon isotopic compositions. But, up to now, carbonates nodules only consuming carbon from oxidized organic matters are rarely documented. Therefore, considering a sustained and ample carbon source, seepage themogenic methane serves as the most reasonable inducement for Xigaze seep carbonate nodules.

Almost all modern marine environments with gas hydrates develop seep carbonates [44-47]. This phenomenon mirrors the close relationship between gas hydrates and seep carbonates. Gas hydrates are environmentally sensitive and are likely to dissociate releasing vast methane as sea level falling and/or bottom seawater temperature increasing. Released methane can serve as the seeping hydrocarbon source, as well, and lead to the precipitation of seep carbonates. Authigenic carbonates related with gas hydrate dissociation usually have positive $\delta^{18} \mathrm{O}$ values [44,46,48]. However, most seep carbonates in Mesozoic and Paleozoic strata have negative $\delta^{18} \mathrm{O}$ values $[13,14,17,24,27,28]$ because of diagenetic alteration. The oxygen isotopic compositions of Xigaze seep carbonates ranging from $-10.7 \%$ o to $-4.3 \%$ o (V-PDB) are obviously lower than the coeval seawater (about $-2 \% o$ according to Veizer et al. [37]). The $\delta^{18} \mathrm{O}$ values among samples vary considerably. The well preserved gray seep carbonates from the first, the second and the third layers have relatively high $\delta^{18} \mathrm{O}$ values from $-8.0 \%$ to $-4.3 \%$ (V-PDB), while the weathered yellow carbonates from the outer parts of the third layer nodule and from the fourth layer show much lower $\delta^{18} \mathrm{O}$ values from $-10.7 \%$ o to $-7.1 \%$. The strongly weathered nodules from the fourth layer, in which pyrite exhibits obvious dissolution, are the most ${ }^{18} \mathrm{O}$-depleted. Micro-drilled samples suggest that the weathered yellow parts have more depleted ${ }^{18} \mathrm{O}$ isotopic compositions than the gray parts (Table 2). These features suggest that the $\delta^{18} \mathrm{O}$ values have close relationships with the degree of weathering, and thus, hypergene weathering might be the main factor causing the ${ }^{18} \mathrm{O}$-depleted isotopic compositions. Therefore, the oxygen isotope compositions of Xigaze seep carbonates should not be used to trace whether there are relationships between the seep carbonate formation and the gas hydrate dissociation.

\subsection{Formation conditions of Xigaze seep carbonates}

The massive seep carbonates from Xigaze develop micrite 
peloids (Figure 3(a)), which are usually interpreted as micritization induced by microbial activities. The laminated carbonates commonly show clotted micrite, which is attributed to varied microenvironments caused by microbial metabolism and thus is considered to represent typical features of microbial carbonates $[14,16,17]$. The occurrences of numerous pyrite framboids with diameters less than $10 \mu \mathrm{m}$ (Figures 3(b),(e) and 4(a)-(c)) suggest the vital function of microbial activities in depositional process of seep carbonates. Previous studies found that the microbial pyrite frambiods have complex inner fabrics [20,49-51]. Pyrite frambiods with sunflower-like fabric composed of elongated crystals as the outer part and granular crystals as the central part were observed in Xigaze seep carbonates (Figure 4(c)). And they are much like the framboids with outer crusts reported from modern seep carbonates [51]. These special fabrics reveal the role of microbe in the formation of Xigaze seep carbonates.

The sparry spheres in Xigaze seep carbonates are very similar to those dark-rimmed spheres in Devonian seep carbonates documented by Peckmann et al. [52,53] both in sizes and morphologies. The only difference among them is that the spheres from Devonian seep carbonates tend to form conglomerations while those observed here are more likely to form single sphere dispersed in micrite matrix. Peckmann et al. [52] proposed an assumption for the formation of these spheres. They suggested that the simple internal fabrics without any partitions or diaphragms of the spheres excluded the biogenic origins, and they considered that the spheres represent former cohesive fluid droplets or bubbles that attracted organic compounds adsorbed to their surfaces. Similar formation mechanisms might also be suitable for the spheres in Xigaze seep carbonates.

$\mathrm{Ce}$ anomalies are used to indicate redox conditions of seep carbonate precipitation environments [50,54-56]. The negative $\mathrm{Ce}$ anomaly indicates oxidizing environments while no or positive $\mathrm{Ce}$ anomaly indicates reducing environments. The $\mathrm{Ce} / \mathrm{Ce}^{*}$ values of Xigaze seep carbonates revised by eliminating La effects show no real Ce anomaly, suggesting slightly reducing conditions. Zhao et al. [57] suggested that the contamination of dissolved clay during sample dissolution will cause errors of REE contents and distribution patterns of the carbonate phases. Yet, Chen et al. [58] did comparative experiments using various acids to leach the powder split from a carbonate sample at different time intervals to obtain the creditable dissolution methods for REE determination. It is found that as long as the reaction time is limited within $30 \mathrm{~min}$, only trace clay will be dissolved by $5 \% \mathrm{HNO}_{3}$, and although total REE contents would increase, the data could still be used to indicate formation conditions. Compared the detected REE results of the soluble phases by $5 \% \mathrm{HNO}_{3}$ for $30 \mathrm{~min}$ and that by $5 \%$ acetic acid for $1 \mathrm{~h}$, it could be concluded that the former method leads to a less than 0.10 increase of $\mathrm{Ce} / \mathrm{Ce}^{*}$ and a less than 0.01 decrease of $\operatorname{Pr} / \operatorname{Pr}^{*}$ [58]. Revised by these two values, only a point transfers from field IIa to field IIIb in Figure 6, indicating negative $\mathrm{Ce}$ anomaly and most samples still remain in the field of no real Ce anomaly. Additionally, all carbonate nodules develop pyrites, which can reveal that they precipitated under anaerobic conditions. Therefore, Xigaze seep carbonates have great consistency with lots of modern and ancient seep carbonates in primary reducing formation environments [50,54-56].

Aragonite and HMC are the most common carbonate phases in modern marine environments including cold seeps. LMC, which is conspicuously absent from normal modern marine settings as non-skeletal carbonates, can be observed in special cold seeps [59]. Which carbonate minerals precipitated at hydrocarbon seeps is believed to be related with the seepage speed to a certain extent. On one hand, increasing methane flux could elevate SMT close to or directly at the seafloor, where the precipitation fluids are strongly affected by seawater. Such a condition favors the precipitation of aragonite and the incorporation of ${ }^{13} \mathrm{C}$-enriched DIC into authigenic carbonate minerals [60]. On the other hand, decreasing methane flux rates over time could make SMT migrate deeper into the sediment, where facilitate the precipitation of HMC. However, the situation must have been different for late Cretaceous seeps because late Cretaceous sea was so called "calcite seas" quite different from today's. Late Cretaceous seawater had $\mathrm{Mg} / \mathrm{Ca}$ mole ratio less than 1 and produced LMC in normal marine settings [61]. Thus, cold seep carbonates in late Cretaceous must have prevalently displayed LMC.

The late Cretaceous Xigaze seep carbonates from the first and the second nodule layers have HMC (Table 1), which was rare in late Cretaceous normal marine settings. During diagenesis the loss of $\mathrm{Mg}$ from HMC and transformation from HMC to LMC are to be expected, whereas the opposite process is unlikely. Hence the HMC in the Xigaze carbonates must be the original. Because the $\mathrm{Mg} / \mathrm{Ca}$ ratio is the most vital factor controlling $\mathrm{Mg}$ fractionation in calcite from the fluid [61], Mg-enriched fluid, which has higher $\mathrm{Mg} / \mathrm{Ca}$ ratio than the coeval seawater, is the necessary condition for HMC precipitation in late Cretaceous "calcite seas". Thus, an Mg-enriched seep fluid for Xigaze seep carbonates is suggested. Seep carbonates from the third and the fourth layers are entirely composed of LMC at present. The LMC could be transformed from HMC during diagenesis, but it is more likely the original owing to their microcrystalline fabrics. Since the various flow flux could cause variability in authigenic carbonate minerals of cold seep carbonates, the mineral compositions of Xigaze seep carbonates might be used to qualitatively trace the seepage fluid flux. Increasing flux could allow SMT to migrate shallower close to or at the seafloor, where the seawater would dilute the seeping fluid. In Xigaze cold seeps, the $\mathrm{Mg}$-enriched seepage fluids would be diluted by the Cretaceous seawater into a low $\mathrm{Mg} / \mathrm{Ca}$ ratio precipitation fluid within the HMC threshold. Such a condition would allow 
LMC, which is very common in late Cretaceous marine settings, to deposit. Therefore, the mineralogy differences among nodules from the first and the second layers and nodules from the third and the fourth layers suggest that the latter formed in higher flux conditions. In addition, previous studies suggested that the rapid seepage activity could lead to relatively heavy carbon isotopic compositions of seep carbonates compared with the slow seepage based on the studies of modern marine seep carbonates [60]. Nodules from the third and the fourth layers have relatively high $\delta^{13} \mathrm{C}$ values (from $-11.6 \%$ to $-4.0 \%$, V-PDB) compared with those from the first and the second layers (from $-27.7 \%$ o to $-18.7 \%$, V-PDB), indicating the third and the fourth layers formed in conditions of higher seepage flux than the first and the second, as well. Additionally, nodules from the fourth layer exhibit smaller sizes and larger quantities, reflecting more nucleation points and faster precipitation speed. This phenomenon should be attributed to a high saturation environment caused by large methane flux and effective AOM. Therefore, based on the mineralogy features, carbon isotopic compositions and the nodule occurrences and sizes, it is proposed that the seeping fluids for the third and the fourth layers had larger flux than that for the first and the second layers.

\section{Conclusions}

Authigenic carbonates occurring as mutually parallel nodules layers are enclosed in turbidite strata of late Cretaceous Xigaze forearc basin. These carbonates develop sedimentary fabrics of clotted micrites, peloids and framboid pyrites, which are similar to that found in modern seep carbonates. The carbonates have $\delta^{13} \mathrm{C}$ value as low as $-27.7 \%$ (V-PDB), suggesting that thermogenic methane as the primary carbon source. Frequently observed pyrites and lack of real $\mathrm{Ce}$ anomaly both indicate a primary reducing precipitation environment of Xigaze seep carbonates. The occurrence of high $\mathrm{Mg}$-calcite in seep carbonates deposited in the late Cretaceous "calcite sea" setting indicates an Mg-enriched seepage fluid. Based on the mineralogy features, carbon isotopic compositions and the nodule occurrences and sizes, it is proposed that the seeping fluids for the third and the fourth layers had larger flux than that for the first and the second layers.

We are grateful to Prof. Wang Chengshan from China University of Geosciences (Beijing) and Huang Chiyue from Department of Earth Sciences, Cheng Kung University, Taiwan, for the guidance of field work. We thank Prof. Wang Fuya from Guangzhou Institute of Geochemistry, CAS for the XRD analysis and the quantification, and Prof. Qi Liang from Institute of Geochemistry, CAS for the analysis of REE. This work was supported by the National Natural Science Foundation of China (41273041). This is contribution No. IS-1542 from GIGCAS.

1 Roberts H H, Aharon P. Hydrocarbon-derived carbonate buildups of the Northern Gulf of Mexico continental slope: A review of submersible investigations. Geo-Mar Lett, 1994, 14: 135-148

2 Chen D, Chen X, Chen G. Geology and geochemistry of cold seepage and venting-related carbonates (in Chinese). Acta Sedimentol Sin, 2002, 20: 34-40

3 Aharon P. Geology and biology of modern and ancient submarine hydrocarbon seeps and vents: An introduction. Geo-Mar Lett, 1994, 14: 69-73

4 Sibuet M, Olu K. Biogeography, biodiversity and fluid dependence of deep-sea cold-seep communities at active and passive margins. DeepSea Res II, 1998, 45: 517-567

5 Chen Z, Yan W, Cheng M, et al. Discovery of seep carbonate nodules as new evidence for gas venting on the northern continental slope of South China Sea. Chin Sci Bull, 2006, 51: 1228-1237

6 Sassen R, Losh S L, Cathles III L M, et al. Massive vein-filling gas hydrate: Relation to ongoing gas migration from the deep subsurface in the Gulf of Mexico. Mar Petrol Geol, 2001, 18: 551-560

7 Judd A G. The global importance and context of methane escape from the seabed. Geo-Mar Lett, 2003, 23: 147-154

8 MacDonald I R, Sager W W, Peccini M B. Gas hydrate and chemosynthetic biota in mounded bathymetry at mid-slope hydrocarbon seeps: Northern Gulf of Mexico. Mar Geol, 2003, 198: 133-158

9 Mazurenko L L, Soloviev V A. Worldwide distribution of deep-water fluid venting and potential occurrences of gas hydrate accumulations. Geo-Mar Lett, 2003, 23: 162-176

10 Campbell K A. Hydrocarbon seep and hydrothermal vent paleoenvironments and paleontology: Past developments and future research directions. Palaeogeogr Palaeoclimatol Palaeoecol, 2006, 232: 362-407

11 Feng D, Roberts $\mathrm{H} \mathrm{H}$. Initial results of comparing cold seep carbonates from mussel- and tubeworm-associated environments at Atwater Valley lease block 340, northern Gulf of Mexico. Deep-Sea Res II, 2010, 57: 2030-2039

12 Boetius A, Ravenschlag K, Schubert C J, et al. A marine microbial consortium apparently mediating anaerobic oxidation of methane. Nature, 2000, 407: 623-626

13 Campbell K A, Farmer J D, Marais D D. Ancient hydrocarbon seeps from the Mesozoic convergent margin of California: Carbonate geochemistry, fluids and palaeoenvironments. Geofluids, 2002, 2: 63-94

14 Peckmann J, Thiel V. Carbon cycling at ancient methane-seeps. Chem Geol, 2004, 205: 443-467

15 Joye S B, Bowles M W, Samarkin V A, et al. Biogeochemical signatures and microbial activity of different cold seep habitats along the Gulf of Mexico deep slope. Deep-Sea Res II, 2010, 57: 1990-2001

16 Peckmann J, Thiel V, Michaelis W, et al. Cold seep deposits of Beauvoisin (Oxfordian; southeastern France) and Marmorito (Miocene; northern Italy): Microbially induced authigenic carbonates. Intl J Earth Sci, 1999, 88: 60-75

17 Peckmann J, Gischler E, Oschmann W, et al. An Early Carboniferous seep community and hydrocarbon-derived carbonates from the Harz Mountains, Germany. Geology, 2001, 29: 271-274

18 Majima R, Nobuhara T, Kitazaki T. Review of fossil chemosynthetic assemblages in Japan. Palaeogeogr Palaeoclimatol Palaeoecol, 2005, 227: 86-123

19 Birgel D, Peckmann J. Aerobic methanotrophy at ancient marine methane seeps: A synthesis. Org Geochem, 2008, 39: 1659-1667

20 Cavalazzi B, Barbieri R, Cady S L, et al. Iron-framboids in the hydrocarbon-related Middle Devonian Hollard Mound of the Anti-Atlas mountain range in Morocco: Evidence of potential microbial biosignatures. Sediment Geol, 2012, 263-264: 183-193

21 Guan $\mathrm{H}$, Feng D, Wu N, et al. Fatty-acids and their $\delta^{13} \mathrm{C}$ characteristics of seep carbonates from the northern continental slope of Gulf of Mexico. Chin Sci Bull, 2010, 55: 730-735

22 Campbell K A, Bottijer D J. Fossil cold seeps. Nat Geogr Res Explor, 1993, 9: 326-343

23 Jenkins R G, Kaim A, Hikida Y, et al. Methane-flux-dependent lateral faunal changes in a Late Cretaceous chemosymbiotic assemblage from the Nakagawa area of Hokkaido, Japan. Geobiology, 2007, 5: 127-139

24 Himmler T, Freiwald A, Stollhofen H, et al. Late carboniferous hy- 
drocarbon-seep carbonates from the glaciomarine Dwyka Group, southern Namibia. Palaeogeogr Palaeoclimatol Palaeoecol, 2008, 257: 185-197

25 Kiel S, Peckmann J. Paleoecology and evolutionary significance of an early Cretaceous Peregrinella-dolominated hydrocarbon-seep deposit on the Crimean Peninsula. Palaios, 2008, 23: 751-759

26 Conti S, Fontana D, Mecozzi S, et al. Late Miocene seep-carbonates and fluid migration on top of the Montepetra intrabasinal high (Northern Apennines, Italy): Relations with synsedimentary folding. Sediment Geol, 2010, 231: 41-54

27 Hammer Ø, Nakrem H A, Little C T S, et al. Hydrocarbon seeps from close to the Jurassic-Cretaceous boundary, Svalbard. Palaeogeogr Palaeoclimatol Palaeoecol, 2011, 306: 15-26

28 Sandy M R, Lazar I, Peckmann J, et al. Methane-seep brachiopod fauna within turbidites of the Sinaia Formation, Eastern Carpathian Mountains, Romania. Palaeogeogr Palaeoclimatol Palaeoecol, 2012, 323-325: 42-59

29 Jiang G, Kennedy M J, Christie-Blick N. Stable isotopic evidence for methane seeps in Neoproterozoic postglacial cap carbonates. Nature, 2003, 426: 822-826

30 Wang J, Jiang G, Xiao S, et al. Carbon isotope evidence for widespread methane seeps in the ca. $635 \mathrm{Ma}$ Doushantuo cap carbonate in south China. Geology, 2008, 36: 347-350

31 Knauth L P, Kennedy M J. The late Precambrian greening of the Earth. Nature, 2009, 460: 728-732

32 Lin Z, Wang Q, Feng D, et al. Post-depositional origin of highly ${ }^{13} \mathrm{C}$-depleted carbonate in the Doushantuo cap dolostone in South China: Insights from petrography and stable carbon isotopes. Sediment Geol, 2011, 242: 71-79

33 Zhou Q, Du Y, Wang J, et al. Characteristics and significance of the cold seep carbonates from the Datangpo Formation of the Nanhua Series in the Northeast Guizhou (in Chinese). J China Univ Geo Sci, 2007, 32: 339-346

34 Wang C, Liu Z, Li X, et al. Xigaze Forearc Basin and Yarlung Zangbo Suture Zone, Tibet (in Chinese). Beijing: Geological Publishing House, 1999. 18-111

35 Roberts H H, Feng D, Joye S B. Cold seep carbonates of the middle and lower continental slope, northern Gulf of Mexico. Deep-Sea Res II, 2010, 57: 2040-2054

36 Bau M, Dulski P. Distribution of yttrium and rare earth elements in the Penge and Kuruman iron-formation Transvaal Supergroup South Africa. Precambrian Res, 1996, 79: 37-55

37 Veizer J, Ala D, Amzy K, et al. ${ }^{87} \mathrm{Sr} /{ }^{86} \mathrm{Sr}, \delta^{13} \mathrm{C}$ and $\delta^{18} \mathrm{O}$ evolution of Paleozoic seawater. Chem Geol, 1999, 161: 59-88

38 Han X, Suess E, Huang Y, et al. Jiulong methane reef: Microbial mediation of seep carbonates in the South China Sea. Mar Geol, 2008, 249: 243-256

39 Sackett W M. Carbon and hydrogen isotope effects during thermocatalytic production of hydrocarbons in laboratory simulation experiments. Geochim Cosmochim Acta, 1978, 42: 571-580

40 Whiticar M J. Faber E, Schoell M. Biogenic methane formation in marine and fresh-water environments: $\mathrm{CO}_{2}$ reduction vs. acetate fermentation-Isotope evidence. Geochim Cosmochim Acta, 1986, 50: 693-709

41 Peckmann J, Campbell K A, Walliser O H, et al. A Late Devonian hydrocarbon-seep deposit dominated by dimerelloid brachiopods, Morocco. Palaios, 2007, 22: 114-122

42 Feng D, Chen D, Su Z, et al. Characteristics of cold seep carbonates and microbial processes in gas seep system (in Chinese). Geoscience, 2005, 19: 26-32

43 Malinverno A, Pohlman J W. Modeling sulfate reduction in methane hydrate-bearing continental margin sediments: Does a sulfate-methane transition require anaerobic oxidation of methane. Geochem Geo- phys Geosys, 2011, 12, Q07006: 1-18

44 Bohrmann G, Greinert J, Suess E, et al. Authigenic carbonates from the Cascadia subduction zone and their relation to gas hydrate stability. Geology, 1998, 26: 647-650

45 Naehr T H, Rodriguez N M, Bohrmann G, et al. Methane derived authigenic carbonates associated with gas hydrate decomposition and fluid venting above the Blake Ridge Diapir. In: Paull C K, Matsumoto R, Wallace P J, et al, eds. Proceedings of the Ocean Drilling Program, Scientific Results. Texas: Ocean Drilling Program, 2000, 164: 285-300

46 Greinert J, Bohrmann G, Suess E. Gas hydrate-associated carbonates and methane-venting at Hydrate Ridge: Classification, distribution and origin of authigenic lithologies. In: Paull C K, Dillon W P, eds. Natural Gas Hydrates: Occurrence, Distribution and Detection. Washington DC: Am Geophys Union, 2001. 99-113

47 Sassen R, Roberts H H, Carney R, et al. Free hydrocarbon gas, gas hydrate, and authigenic minerals in chemosynthetic communities of the northern Gulf of Mexico continental slope: Relation to microbial processes. Chem Geol, 2004, 205: 195-217

48 Aloisi G, Pierre C, Rouchy J M, et al. Methane-related authigenic carbonates of eastern Mediterranean Sea mud volcanoes and their possible relation to gas hydrate destabilization. Earth Planet Sci Lett, 2000, 184: 321-338

49 Chen D, Feng D, Su Z, et al. Pyrite crystallization in seep carbonates at gas vet and hydrate site. Mater Sci Eng C, 2006, 26: 602-605

50 Feng D, Chen D, Qi L, et al. Petrographic and geochemical characterization of seep carbonate from Alaminos Canyon, Gulf of Mexico. Chin Sci Bull, 2008, 53: 1716-1724

51 Zhang M, Sun X, Lu Y, et al. Mineralogy of authigenic tube pyrite from the Southwest Taiwan Basin of South China Sea and its tracing significance for gas hydrates (in Chinese). Mineral Deposits, 2011, 30: 725-734

52 Peckmann J, Walliser O H, Riegel W, et al. Signatures of hydrocarbon venting in a middle Devonian Carbonate Mound (Hollard Mound) at the Hamar Laghdad (Antiatlas, Morocco). Facies, 1999, 40: 281-296

53 Peckmann J, Little C T S, Gill F, et al. Worm tube fossils from the Hollard Mound hydrocarbon-seep deposit, Middle Devonian, Morocco: Palaeozoic seep-related vestimentiferans. Palaeogeogr Palaeoclimatol Palaeoecol, 2005, 227: 242-257

54 Birgel D, Feng D, Roberts $\mathrm{H} \mathrm{H}$, et al. Changing redox conditions at cold seeps as revealed by authigenic carbonates from Alaminos Canyon, northern Gulf of Mexico. Chem Geol, 2011, 285: 82-96

55 Feng D, Chen D, Peckmann J. Rare earth elements in seep carbonates as tracers of variable redox conditions at ancient hydrocarbon seeps. Terra Nova, 2009, 21: 49-56

56 Ge L, Jiang S, Swennen R, et al. Chemical environment of cold seep carbonate formation on the northern continental slope of South China Sea: Evidence from trace and rare earth element geochemistry. Mar Geol, 2010, 277: 21-30

57 Zhao Y, Zheng Y, Chen F. Trace element and strontium isotope constraints on sedimentary environment of Ediacaran carbonates in southern Anhui, South China. Chem Geol, 2009, 265: 345-362

58 Chen L, Li C, Chen D. The analysis of solution-ICP-MS of rare earth elements of carbonate minerals in carbonate rocks. Goldschmidt, 2012, 24-29 June

59 Feng D, Roberts H H. Geochemical characteristics of the barite deposits at cold seeps from the northern Gulf of Mexico continental slope. Earth Planet Sci Lett, 2011, 309: 89-99

60 Burton E A. Controls on marine carbonate cement mineralogy: Review and reassessment. Chem Geol, 1993, 105: 163-179

61 Stanley S M, Ries J B, Hardie L A. Low-magnesium calcite produced by coralline algae in seawater of Late Cretaceous composition. Geology, 2002, 99: 15323-15326

Open Access This article is distributed under the terms of the Creative Commons Attribution License which permits any use, distribution, and reproduction in any medium, provided the original author(s) and source are credited. 